\title{
REMOVAL OF ORGANIC MATERIAL IN FREE WATER SURFACE GRAVEL BED FILTERS
}

\author{
Aloyce W. Mayo ${ }^{1}$ and Hesborne S. Ogombe ${ }^{2}$ \\ ${ }^{1}$ Department of Water Resources Engineering, University of Dar es Salaam \\ P.O. Box 35131, Dar es Salaam. \\ ${ }^{2}$ Department of Agricultural Engineering and Technology, \\ Egerton University, Nakuru, Kenya \\ E-mail: aloyce.mayo@yahoo.com
}

\begin{abstract}
The removal of organic material in free surface gravel bed filters was investigated and modelled. Two pilot wetland units of $7.5 \mathrm{~m} \times 1.5 \mathrm{~m} \times 0.7 \mathrm{~m}$ were constructed adjacent to the University of Dar es Salaam waste stabilization ponds to receive maximum organic and hydraulic loading rates of less than $185 \mathrm{~kg} / \mathrm{ha} / \mathrm{d}$ and 110 $\mathrm{l} / \mathrm{m}^{2} / d$, respectively. These units received wastewater of domestic characteristics from primary stabilization pond. The entire depth of $0.7 \mathrm{~m}$ of the wetland units were packed with gravel of size $8 \sim 25 \mathrm{~mm}$ and porosity of 35\%. Samples were collected from the influent and effluent of wetland units and were tested for chemical oxygen demand (COD), temperature, dissolved oxygen, $\mathrm{pH}$ and other parameters useful for testing of the model. A semi-empirical model representing the major processes taking place in the wetland units was developed by incorporating suspended biomass, biofilm biomass, and sedimentation and filtration components. The model was optimized using computer program. The model was successfully developed and showed that biofilm of gravel media contributed significantly to COD removal in wetlands.
\end{abstract}

Key words: Gravel bed filters, Organic material removal, Wetlands

\section{INTRODUCTION}

The use of constructed wetland systems to treat wastewater is an emerging technology in the world (Cooper et al., 1996; Shutes et al., 1997; Mungur et al., 1998). Constructed wetlands have been used worldwide because such systems have proved to be an effective low-cost technology for removing nutrient, suspended solids, pathogenic organisms and organic material from wastewater (Mayo and Kalibbala, 2007; Kalibbala et al., 2008; Gerberg et al., 1985). Their capital cost is low, operational and maintenance requirements is low; but still remove over $70 \%$ of solids, bacteria, and organic matter.
They have further been used in industrial wastewater treatment systems where toxicity is not a problem, storm water runoff treatment, as well as in the treatment of agricultural and non-point source pollution. However, surface constructed wetlands attract disease-causing vectors such as mosquitoes and snails; and they cause a great danger of clogging due to suspended solids (Kadlec and Knight, 1996).

There are numerous potential fates for nutrients entering a constructed wetland via the wastewater, which determine the removal capability of these substances from the wastewater (Kadlec and Knight, 1996; 
Zhang et al., 2015). The major nutrient removal pathways in constructed wetlands are loss to the atmosphere, drainage from the wetland, and retention in the wetland sinks. Nutrient accumulation in a wetland sink is a function of both the mass of the sink, and the concentration of nutrients in the sink (Mayo and Hanai, 2017). Whilst a number of studies have investigated nutrient accumulation by wetland macrophytes (Duarte, 1992; Greenway, 1997; Mayo and Bigambo, 2005; Mayo et al., 2018), little work has investigated nutrient partitioning and translocations in other wetland sinks. The removal of organic and inorganic matter from wastewater, as well as bacteria, using macrophytes has been explained by means of several mechanisms such as sedimentation, mechanical filtration or nutrient assimilation into plants (Brix, 1995; Mayo, 2014).

Despite this evidence, there is controversy on the function of macrophytes for wastewater treatment in artificial wetlands. Some researchers have found an improvement in wastewater treatment in presence of macrophytes (Rogers et al., 1991; Farahbakhshazad et al., 1995), while other studies did not detect significant differences between planted and unplanted systems (Tanner et al., 1995). Nevertheless, comparisons between studies are difficult because they utilize diverse aquatic plant species and water flows.

Nutrients in wastewater comprise mainly of carbon, nitrogen and phosphorus, which can lead to eutrophication and dissolved oxygen depletion. The presence of carbon in wastewater is detrimental to the downstream users of the water bodies into which such wastewater is discharged. The breakdown of particulate and soluble carbon draws oxygen from the system. When the level of dissolved oxygen drops substantially, the dissolved oxygen deficit causes anoxic conditions, which are harmful to aquatic life. Hence removal of nutrients from wastewater is very necessary. The objectives of this research are to develop a model for COD removal and determine the model parameters through selected optimisation procedures.

\section{METHODS AND MATERIALS}

Two wetland units of $7.5 \mathrm{~m} \times 1.5 \mathrm{~m} \times 0.7 \mathrm{~m}$ were constructed adjacent to the University of Dar es Salaam waste stabilization ponds to accommodate flow rate of about $1 \mathrm{~m}^{3} / \mathrm{d}$ (Fig. 1). The organic and hydraulic loading rates were limited to less than $185 \mathrm{~kg} / \mathrm{ha} / \mathrm{d}$ and $110 \mathrm{l} / \mathrm{m}^{2} / \mathrm{d}$, respectively. These units received wastewater of domestic characteristics from primary stabilization pond. The entire depth of $0.7 \mathrm{~m}$ of the wetland units were packed with gravel of size $8 \sim 25 \mathrm{~mm}$ and porosity of $35 \%$.

Samples were taken at the influent and effluent points of the constructed wetland for analysis. Side sampling was also carried out through the fifteen side sampling points of the cell. The samples were collected in 250 $\mathrm{ml}$ sampling bottles at around 10 a.m. every sampling day. Collected samples were quickly taken to the laboratory for analysis, in an effort to minimize the holding time. Prompt analysis of samples helped minimize reduction of $\mathrm{COD} / \mathrm{BOD}$; otherwise the samples should be cooled to near freezing temperature during storage.

Determination of COD was carried out in the laboratory using the closed reflux titrimetric method as described by the Standard Methods (1996). BOD 5 tests were also conducted on the collected samples in standard half litre bottles incubated at $20^{\circ} \mathrm{C}$ for 5 days. The BOD for each sample was measured using the manometric method. Temperature and $\mathrm{pH}$ measurements were carried out using temperature electrode and pH-meter (metrohm type, model 704), 
respectively. Dissolved oxygen was measured in-situ using a DO meter, model 50B. Turbidity was measured using a direct reading spectrometer $(D R / 2000)$. The total suspended solids (TSS) were measured using membrane filtration technique in accordance with Standard Methods (2012).
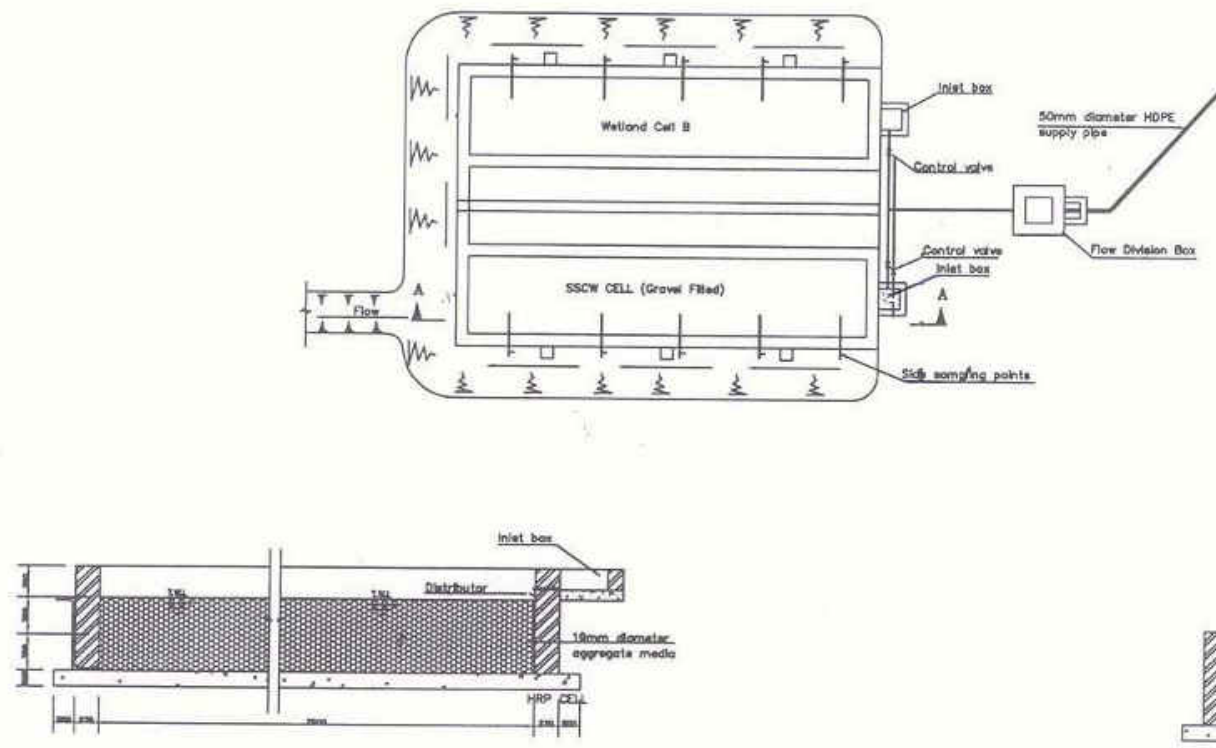

SECTON A-A
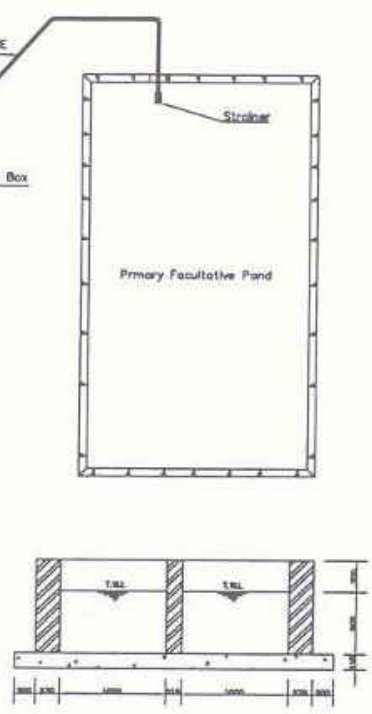

SRCTON B B B

Figure 1: Layout of experimental wetlands

\section{RESULTS AND DISCUSSION}

\section{Variation of the Chemical Oxygen demand (COD)}

Table 1 show that the measured daily influent COD values were in the range of $103-205 \mathrm{mg} / \mathrm{l}$, with an average of $148 \mathrm{mg} / \mathrm{l}$. These values were always higher than the effluent values, which ranged from $17-171$ $\mathrm{mg} / \mathrm{l}$, with an average of $68 \mathrm{mg} / \mathrm{l}$. The difference between daily influent and effluent values indicates the magnitude of COD removed by the system on the given day. This difference, when divided by the influent value of a given day, gives the efficiency of the system (for that day) in biodegrading organic carbon. These daily efficiency values were in the range of 16.7 $85.7 \%$, with an average of $53.1 \%$. The efficiency value indicated as $16.7 \%$ is too low in comparison with the rest because prior to the day when the data corresponding to this value was collected, a heavy rainstorm had caused runoff to flow into the cell from the primary facultative pond that had overflowed.

Figure 3 shows that COD generally decreased down the length of the wetland cell. This is because the wastewater towards the effluent point had stayed in the system for a longer duration than the incoming wastewater, and thus microorganisms had adequate time to biodegrade organic matter in the wastewater. Wastewater entering into the system left through the outlet point with lower levels of organic carbon (of which COD is a measure), which is an indication that the system worked effectively. 
Table 1: Variation of Physical-chemical parameters in water hyacinth wetland

\begin{tabular}{|l|l|c|c|c|c|}
\hline \multirow{2}{*}{ No } & \multirow{2}{*}{ Parameter } & \multicolumn{2}{|c|}{ Influent } & \multicolumn{2}{c|}{ Effluent } \\
\cline { 3 - 5 } & & Range & Mean & Range & Mean \\
\hline 1. & $\mathrm{pH}$ & $7.11 \sim 7.89$ & 7.59 & $7.52 \sim 8.86$ & 8.10 \\
\hline 2. & Dissolved oxygen $(\mathrm{mg} / \mathrm{l})$ & $0.27 \sim 3.07$ & 1.87 & $0.16 \sim 4.09$ & 2.06 \\
\hline 3. & Temperature $\left({ }^{\circ} \mathrm{C}\right)$ & $26.6 \sim 32.5$ & 30.3 & $26.9 \sim 31.3$ & 29.6 \\
\hline 4. & Chemical Oxygen Demand $(\mathrm{mg} / \mathrm{l})$ & $103 \sim 205$ & 148 & $17 \sim 171$ & 68 \\
\hline
\end{tabular}

Figures 2 and 3 shows a localized effect in the COD trend towards the end of the unit. There are two possible reasons for this phenomenon. The first one is re-suspension of suspended solids as the wastewater leaves from the bottom of the surface constructed wetland cell. Secondly, wind drifts of the duckweed caused a higher concentration of detritus towards the end of the cell. The plant used to be blown by wind and get drifted to the leeward side of the pond (the effluent end of the cell) mainly because the system did not have baffles. When the plants died, detritus first settled to the bottom of the pond and were thereafter re-suspended towards the surface. The microorganisms responsible for biodegrading organic carbon exerted a higher demand for oxygen, and consequently resulting on higher COD values.

\section{DEVELOPMENT OF THE MODEL}

A mathematical model was developed to incorporate major mechanisms influencing the removal of COD from wastewater in constructed wetlands. These mechanisms include biofilm activities, sedimentation and filtration. The model describes the main characteristics of the ecosystem and the related problems in mathematical terms. By use of this model, processes taking place in the wetland can be converted into different mathematical equations and solved with an aid of a computer program.

Plug flow conditions were assumed to approximately hydraulic conditions in the wetland cell, and hence equation (1) was used to obtain the observed rates of reaction.

$$
C_{e} / C_{o}=\exp \left(-k_{T} t\right)
$$

Where: $\mathrm{k}_{\mathrm{T}}=$ Temperature dependent first order COD removal rate in $\mathrm{d}^{-1}, \mathrm{C}_{\mathrm{e}}$ and $\mathrm{C}_{\mathrm{o}}$ are the effluent and influent chemical oxygen demand in $\mathrm{mg} / \mathrm{l}$, respectively, and $\mathrm{t}=$ hydraulic retention time (d).

\section{The biofilm component}

This portion of the model involves substrate mass balances in the bulk liquid flow and in the biofilm. It incorporates the activities of both the suspended biomass and the biofilm on the walls. The overall reaction rate constant is given as the sum of these two (Polprasert and Agarwalla, 1994).

$$
\mathrm{k}=\mathrm{k}_{\mathrm{fs}}+\mathrm{a}_{\mathrm{s}} \frac{\alpha \beta}{\alpha+\beta}
$$

Where: $\mathrm{k}_{\mathrm{fs}}=$ first order reaction rate constant of suspended biomass. This factor is corrected for temperature as given by equation (3):

$$
\left(\mathrm{k}_{\mathrm{fs}}\right)_{\mathrm{T}}=\left(\mathrm{k}_{\mathrm{fs}}\right)_{20} \theta^{(\mathrm{T}-20)}
$$




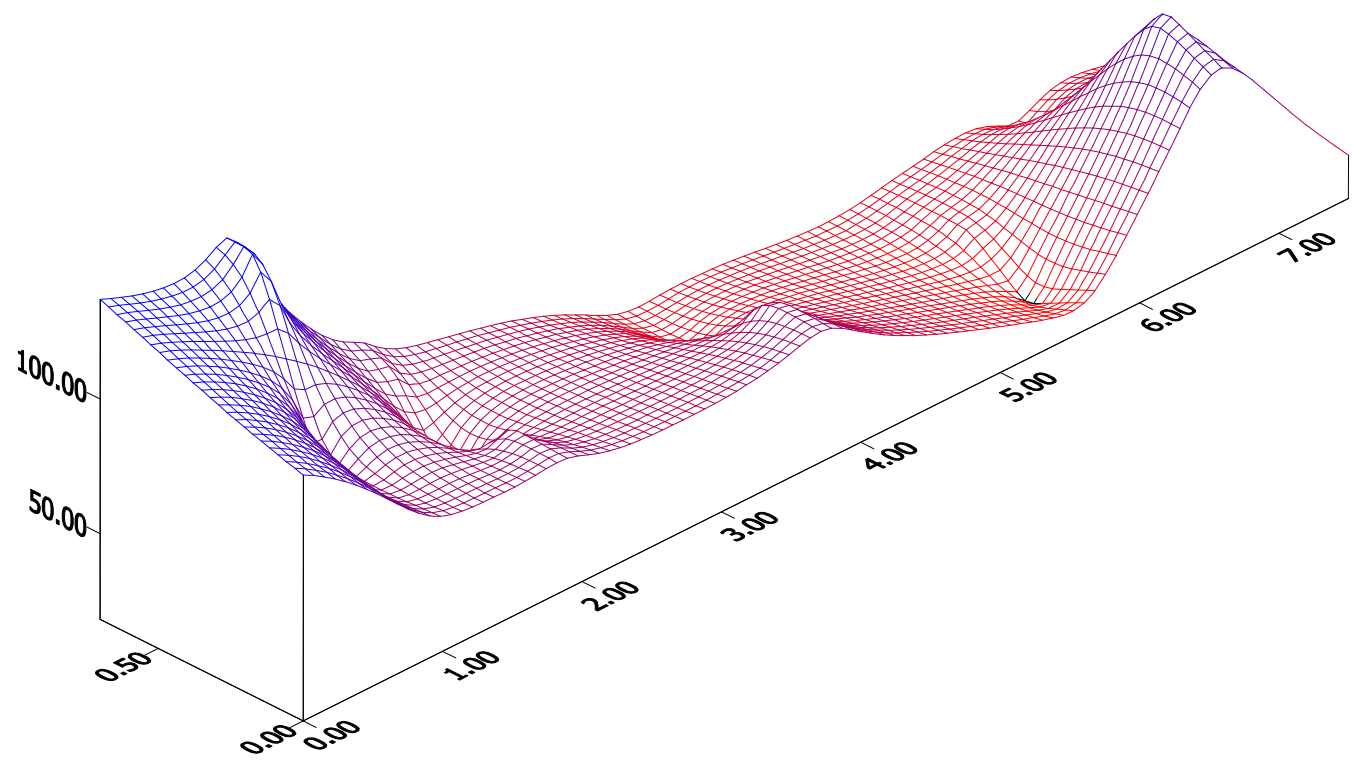

Fig. 2: Three-dimensional representation of the variation of COD in the wetland cell.

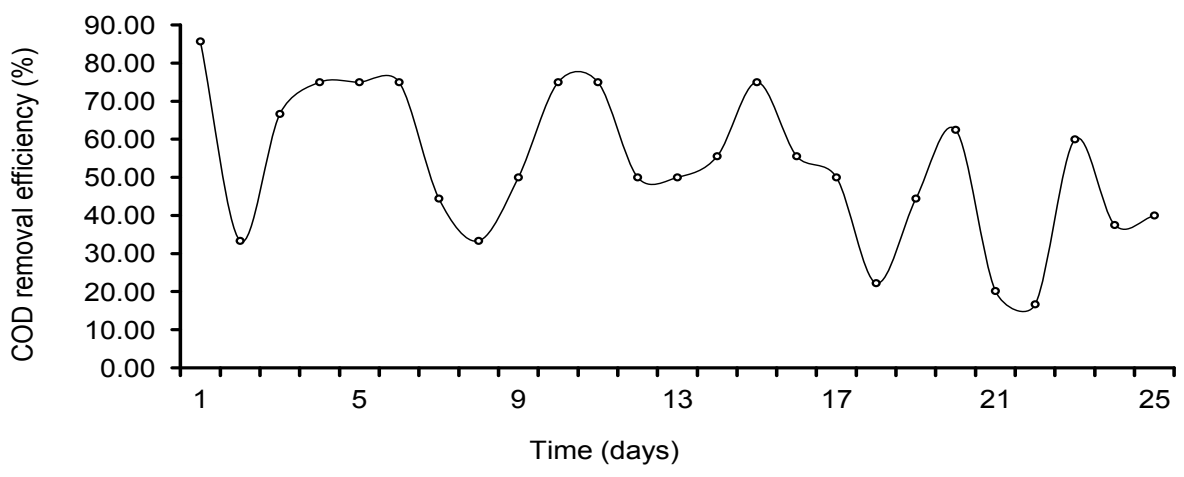

Fig. 3: Variation of COD removal efficiency with time.

where $\left(\mathrm{k}_{\mathrm{fs}}\right)_{\mathrm{T}}$ and $\left(\mathrm{k}_{\mathrm{fs}}\right)_{20}$ are the $\mathrm{k}_{\mathrm{fs}}$ values at the water temperature (T) and at $20{ }^{\circ} \mathrm{C}$, respectively. During programming in FORTRAN-77, the value of $\left(\mathrm{k}_{\mathrm{fs}}\right)_{20}$ was varied between 0.001 and 10.0; and an optimum value was obtained to be $\left(\mathrm{k}_{\mathrm{fs}}\right)_{20}=$ $0.011 \mathrm{~d}^{-1}$. Optimum temperature coefficient $\theta$ of 1.0034 was obtained, which is reasonably close to values reported in literature. Metcalf and Eddy Inc. (1995) has reported the $\theta$ ranges 1.00-1.08, 1.04-1.10 and 1.02-1.08 for activated sludge, aerated lagoons and trickling filters; with typical values of 1.04 , 1.08 , and 1.035 , respectively.

Parameter $a_{s}=$ specific surface area, $\mathrm{m}^{2} / \mathrm{m}^{3}$. For ponds without baffles or other attached growth media, $a_{s}=2 / W+1 / y+2 / L$, where $\mathrm{L}, \mathrm{W}$, and $\mathrm{y}$ are the dimensions of the cell length, width and depth, respectively. This expression for $a_{\mathrm{s}}$ shows that its magnitude is constant and depends upon pond dimensions 
as determined during the design stage. During this study, parameter $\mathrm{a}_{\mathrm{s}}=3.02857$ $\mathrm{m}^{2} / \mathrm{m}^{3}$ for the cell dimensions $\mathrm{L}=7.5 \mathrm{~m}, \mathrm{~W}$ $=1.5 \mathrm{~m}$ and $\mathrm{y}=0.7 \mathrm{~m}$.

$$
\alpha=\mathrm{D}_{\mathrm{w}} / \mathrm{L}_{\mathrm{s}}
$$

Where $\mathrm{D}_{\mathrm{w}}=$ diffusion coefficient responsible for diffusivity of a substrate through a stagnant liquid (water). Perry and Chilton (1973) reported a value of $D_{w}=52.6 \times 10^{-6}$ $\mathrm{m}^{2} /$ day at $30.4{ }^{\circ} \mathrm{C}, \mathrm{L}_{\mathrm{s}}$ is the liquid sublayer thickness, obtained as $\mathrm{L}_{\mathrm{s}}=200 \times 10^{-6} \mathrm{~m}$ by Polprasert and Agarwalla (1994).

$$
\beta=(\tanh \phi / \phi) . \mathrm{k}_{\mathrm{fa}} . \mathrm{L}_{\mathrm{f}}
$$

In which: $\phi$ is the characteristic biofilm parameter given as:

$$
\phi=\left(\mathrm{k}_{\mathrm{fa}} \mathrm{L}_{\mathrm{f}}^{2} / \mathrm{D}_{\mathrm{f}}\right)^{0.5}
$$

$\mathrm{k}_{\mathrm{fa}}$ is the first - order rate constant of biofilm biomass usually determined in the laboratory through batch experiments. A value of $\mathrm{k}_{\mathrm{fa}}=$ 336.6 day $^{-1}$ was obtained by Polprasert and Agarwalla (1994) at an actual average temperature of $30.4^{\circ} \mathrm{C}$.

The first order rate constant of biofilm biomass at $20^{\circ} \mathrm{C},\left(\mathrm{k}_{\mathrm{fa}}\right)_{20}$ and that at any other temperature $(\mathrm{T})$, are related by equation (6):

$$
\left(\mathrm{k}_{\mathrm{fa}}\right)_{\mathrm{T}}=\left(\mathrm{k}_{\mathrm{fa}}\right)_{20} \theta^{(\mathrm{T}-20)}
$$

Polprasert and Agarwalla (1994), in their investigation of the significance of biofilm activity in facultative pond design and performance, obtained a value of $\left(\mathrm{k}_{\mathrm{fa}}\right)_{20}=$ 151.2 day $^{-1}$ for two different facultative ponds located in Bangkok, Thailand and New Mexico city, USA.

$\mathrm{L}_{\mathrm{f}}$ is the biofilm thickness. By installing polyvinyl chloride (PVC) sheets each 200 $\mathrm{mm} \times 300 \mathrm{~mm}$ x $3 \mathrm{~mm}$ : width $\times$ length $\times$ thickness in a pilot-scale facultative pond treating wastewater of the Asian Institute of Technology (AIT) campus, Bangkok, Thailand, Polprasert and Agarwalla (1994) obtained $\mathrm{L}_{\mathrm{f}}=1538 \mu \mathrm{m} . \mathrm{D}_{\mathrm{f}}$ is the diffusivity of a substrate in biofilm, usually considered constant or independent of concentration. Using zero-order substrate removal kinetics, Lamotta (1976) found the $\mathrm{D}_{\mathrm{f}}$ value of $30.4 \mathrm{x}$ $10^{-6} \mathrm{~m}^{2} /$ day at a temperature of $30^{\circ} \mathrm{C}$.

\section{The sedimentation component}

The reaction rate constant contributed by sedimentation is given by the following equation (8), modified from O'Melia (1985), as reported by Khatiwada and Polprasert (1997).

$\mathrm{k}_{\mathrm{sed}}=\frac{3}{2} \frac{\left(\rho_{p}-\rho_{w}\right) g d_{p}^{2}}{18 \mu U} \lambda \frac{U(1-n)}{d_{c}}$

Where: $\rho_{p}=$ density of colloidal matter particle. It ranges between 1100 - 1500 $\mathrm{kg} / \mathrm{m}^{3}$ (Metcalf and Eddy Inc., 1995), $\rho_{w}=$ density of water $=1000 \mathrm{~kg} / \mathrm{m}^{3}, \mathrm{~g}=$ acceleration due to gravity $=9.81 \mathrm{~m} / \mathrm{s}^{2}, \mathrm{~d}_{\mathrm{p}}=$ diameter of colloidal matter particle, ranging between $1-10 \mu \mathrm{m}$ (Metcalf and Eddy Inc., 1995), $\mu=$ the dynamic viscosity of water, related to temperature of water $\left(\mathrm{T}^{\circ} \mathrm{C}\right)$ by the following relationship suggested by Weast (1981) for the temperature range $20^{\circ} \mathrm{C} \leq \mathrm{T} \leq$ $100^{\circ} \mathrm{C}$.

$\log \left(\frac{\mu}{\mu_{20}}\right)=\left[1.3272(20-\mathrm{T})-0.001053(\mathrm{~T}-20)^{2}\right] /(\mathrm{T}+105)$

For water, $\mu=1 \times 10^{-2}$ poise, and $\mu_{20}=1.002$ $\mathrm{x} 10^{-2}$ poise $=1.002 \times 10^{-3} \mathrm{~N} . \mathrm{s} / \mathrm{m}^{2}$
$\mathrm{U}=\mathrm{Q}_{\mathrm{o}} / \mathrm{w} \mathrm{y}_{1}$ is the velocity of flow of wastewater through the wetland cell, where $\mathrm{Q}_{\mathrm{o}}$ is the flow rate of the influent water $(=1$ 
$\mathrm{m}^{3} /$ day), $\mathrm{w}$ is the width of the cell and $\mathrm{y}_{1}=$ $0.35 \mathrm{~m}$ is the depth of wastewater above the aggregate medium. Parameter $\lambda$ is the sticking coefficient was optimized within the range of 0.0001 to10 using the Fortran computer program. The optimum value of $\lambda$ was 0.001. Parameter $\mathrm{n}=0.35$ is the porosity of bed, and $\mathrm{d}_{\mathrm{c}}=$ diameter of collector $=0.01905 \mathrm{~m}$ for the aggregate used.

\section{Filtration component}

The bottom portion of the wetland cell is assumed to act as a trickling filter; and that filtration occurs within the aggregate medium between cell depth $0.35-0.7 \mathrm{~m}$. The general form of Germain (1966) model given in equation (10) is used to account for the contribution of filtration in the overall cell model.

$$
\frac{C_{e}}{C_{o}}=\exp \left[-k_{20} D\left(Q_{v}\right)^{-m}\right]
$$

Where: $\mathrm{C}_{\mathrm{e}}=\mathrm{COD}$ of settled effluent from the filter $(\mathrm{mg} / \mathrm{l}), \mathrm{C}_{\mathrm{o}}=\mathrm{COD}$ of wastewater applied to the filter $(\mathrm{mg} / \mathrm{l}), \mathrm{k}_{20}=$ reaction rate constant corresponding to a specific filter medium of depth $\mathrm{D}$ at $20^{\circ} \mathrm{C}, \mathrm{D}=$ depth of filter $(\mathrm{m}), \mathrm{Q}_{\mathrm{v}}=\frac{Q}{A}=$ volumetric flow rate applied per unit area of filter $\left(\mathrm{m}^{3} / \mathrm{s} . \mathrm{m}^{2}\right), \mathrm{Q}=$ flow rate applied to filter without recirculation $\left(\mathrm{m}^{3} / \mathrm{s}\right), \mathrm{A}=$ cross-sectional area of filter $\left(\mathrm{m}^{2}\right)$, and $\mathrm{m}=$ experimental constant. An optimum value of $\mathrm{m}=1.2$ was obtained for this parameter through optimization.

The COD reaction rate constant, $\mathrm{k}_{20}$ in equation (3) takes into account the rate constant $\mathrm{k}_{\mathrm{T}}$.

These two constants are related as follows:

$$
\mathrm{K}_{20}=\frac{k_{T}}{\theta^{(T-20)}}
$$

Substituting this expression for $\mathrm{K}_{20}$ in equation (11) into equation (10) and making $\mathrm{k}_{\mathrm{T}}$ the subject yields:

$$
\mathrm{k}_{\mathrm{T}}=\frac{-(\theta)^{T-20} \operatorname{In}\left(\frac{C_{e}}{C_{o}}\right)}{D\left(Q_{v}\right)^{-m}}
$$

Equation (12) is taken as the fourth component of the COD model. Basing on all these model parameters, the proposed model is therefore:

$\mathrm{k}_{\text {pred }}=\left[\left(\mathrm{k}_{\mathrm{fs}}\right)_{20} \theta^{(\mathrm{T}-20)}\right]+\left(\mathrm{a}_{\mathrm{s}} \frac{\alpha \beta}{\alpha+\beta}\right)+\left\{\frac{3}{2} \frac{\left(\rho_{p}-\rho_{w}\right) g d_{p}^{2}}{18 \mu U} \lambda \frac{U(1-n)}{d_{c}}\right\}+\left(\frac{-(\theta)^{T-20} \operatorname{In}\left(\frac{C_{e}}{C_{o}}\right)}{D\left(Q_{v}\right)^{-m}}\right) \ldots$

Or $\mathrm{k}_{\text {pred }}=$ [suspended biomass term $]+($ biofilm term $)+\{$ sedimentation term $\}+($ filter effect $)$

\section{The observed removal rate constant, $\boldsymbol{k}_{\text {obs }}$}

The observed removal rate constant was calculated from equation (1); i.e.

$$
\mathrm{k}_{\mathrm{obs}}=-\frac{1}{t} \operatorname{In}\left(\frac{C_{e}}{C_{o}}\right)
$$

The retention time $(\mathrm{t})$ is taken to be 5.3 days and $\mathrm{C}_{\mathrm{e}}$ and $\mathrm{C}_{\mathrm{o}}$ are the effluent and influent COD values measured daily, respectively.

\section{Parameter optimisation and model application}

A computer program in FORTRAN was written for the wetland cell model in equation (13). Unknown model coefficients were optimized within appropriate ranges using FORTRAN computer programming language; and the optimized values, along with other model parameters obtained both from literature and from the field, used in the 
model to yield predicted (or estimated) values. The results of the optimized parameters are summarized in Tables 1 and 2 . The constructed wetland cell model for COD removal expressed by equation (13) can be used to provide predicted daily values of COD removal rate constants $\mathrm{k}_{\text {pred. These }}$ predicted removal rate values, together with the plug flow equation, can give predicted effluent COD values at the various corresponding influent COD measurements, $\mathrm{C}_{\mathrm{e} \text { pred }}$, as expressed in equation (15).

$$
\mathrm{C}_{\text {e pred. }}=\mathrm{C}_{\mathrm{o}} \exp \left(-\mathrm{t}^{*}\left[\left\{0.011 * 1.0034^{(\mathrm{T}-20)}\right\}+\left\{(0.0543) \mathrm{a}_{\mathrm{s}}\right\}+\left\{\frac{-(1.0034)^{T-20} \operatorname{In}\left(\frac{C_{e}}{C_{o}}\right)}{D(Q / A)^{-1.2}}\right\}\right]\right)
$$

Table 2: Optimum model parameters

\begin{tabular}{|l|l|l|l|}
\hline Parameter & Optimization Range & Optimum Value & Units \\
\hline $\mathrm{d}_{\mathrm{p}}$ & $(0.01-300000)^{*} 10^{-6}$ & $1 * 10^{-6}$ & $\mathrm{~m}$ \\
\hline$\rho_{p}$ & $1050-1200$ & 1100 & $\mathrm{~kg} / \mathrm{m}^{3}$ \\
\hline$\lambda$ & $0.0001-10$ & 0.001 & Dimensionless \\
\hline$\theta$ & $0.5-1.5$ & 1.0034 & Dimensionless \\
\hline $\mathrm{m}$ & $0.1-2.5$ & 1.2 & Dimensionless \\
\hline$\left(\mathrm{k}_{\mathrm{fs}}\right)_{20}$ & $0.001-10$ & 0.011 & $\mathrm{~d}^{-1}$ \\
\hline
\end{tabular}

Table 3: Summary of other parameters used in the model

\begin{tabular}{|l|l|l|l|}
\hline Parameter & Units & Magnitude & Source \\
\hline $\mathrm{a}_{\mathrm{s}}:$ specific surface area & $\mathrm{m}^{2} / \mathrm{m}^{3}$ & 3.02857 & Weast (1981) \\
\hline$\alpha:$ biofilm parameter & $\mathrm{m} /$ day & 0.263 & Perry and Chilton (1973) \\
\hline$\beta:$ biofilm parameter & $\mathrm{m} /$ day & 0.0687 & Polprasert and Agarwalla (1994) \\
\hline$\rho_{\mathrm{w}}:$ density of water & $\mathrm{Kg} / \mathrm{m}^{3}$ & 1000 & Standard value \\
\hline $\mathrm{g}:$ gravitational acceleration & $\mathrm{m} / \mathrm{s}^{2}$ & 9.81 & Standard value \\
\hline$\mu:$ kinematic viscosity & $\mathrm{N} . \mathrm{s} / \mathrm{m}^{2}$ & $1 * 10^{-3}$ & Weast (1981) \\
\hline U: flow velocity & $\mathrm{m} / \mathrm{s}$ & $2.2^{*} 10^{-5}$ & From the field \\
\hline $\mathrm{n}:$ porosity of the bed & - & 0.35 & From the field \\
\hline $\mathrm{d}_{\mathrm{c}}:$ diameter of collector & $\mathrm{m}$ & 0.01905 & From the field \\
\hline $\mathrm{D}:$ depth of gravel medium & $\mathrm{m}$ & 0.35 & From the field \\
\hline
\end{tabular}

\section{Trends in the observed and predicted reaction rates}

Fig. 4 shows the variation of observed and predicted COD removal rate constants with time. When the values of the predicted COD removal rate constants are plotted against the observed ones, the linear regression relationship $\mathrm{k}_{\text {pred }}=0.8559 \mathrm{k}_{\mathrm{obs}}+0.0215$ was obtained. This implies that the model can be used to estimate predicted removal rates very well, for any given observed rates. The observed effluent COD values were always lower than those of the influent indicating that the wetland cell removed organic carbon from the wastewater. 
The kinks in the three graphs imply that there were, on some days of data observation, vast differences in measured/observed values with reference to the previous day's measurement. In particular, the last high peak, having an extremely high influent COD value of 205 $\mathrm{mg} / \mathrm{l}$ and a correspondingly low COD removal efficiency of $17 \%$ (Table 1), was caused by flooding of the wetland cell. On a day prior to that of this measurement, a heavy downpour of rain had resulted into overtopping of the banks of the primary facultative pond (labeled 'A' in Fig. 1) and the accrued runoff found its way into the constructed wetland cell. Table 1 also shows that a magnitude of $34 \mathrm{mg} / \mathrm{l}$ COD was removed from the wastewater that day, an amount almost equal to that removed on the second day of data collection when the system efficiency was fairly high (33\%). This observation emphasizes the fact that flooding did not, nevertheless, cause poor performance of the wetland system; and that high effluent COD values were obtained for the sole reason that the influent organic loading rate must have been excessively high as a result of the runoff.

\section{Application of the model for prediction of effluent COD}

The constructed wetland cell model for COD removal expressed by equation (13) can be used to provide predicted daily values of COD removal rate constants $\mathrm{k}_{\text {pred}}$. These predicted removal rate values, together with the plug flow equation, can give predicted effluent COD values at the various corresponding influent COD measurements, $\mathrm{C}_{\mathrm{e} \text { pred, }}$ as expressed in equation (15).

\section{CONCLUSIONS}

The main factors influencing the removal of carbon from wetlands are abiotic factors such as $\mathrm{pH}$, temperature and DO; wetland plants organic loading rates and retention time. A semi-empirical model developed for the system comprises of four components namely suspended biomass, biofilm activities, sedimentation and filtration. Upon optimization of the model parameters using information obtained from both the field and literature, the model gave the values $\lambda=$ 0.001 for the sticking coefficient, temperature coefficient $\theta=1.0034, \mathrm{~m}=1.2$ for the experimentation constant in infiltration, and the first order reaction rate constant for suspended biomass at $20^{\circ} \mathrm{C}$, $\left(\mathrm{k}_{\mathrm{fs}}\right)_{20}=0.011 \mathrm{~d}^{-1}$, respectively. 


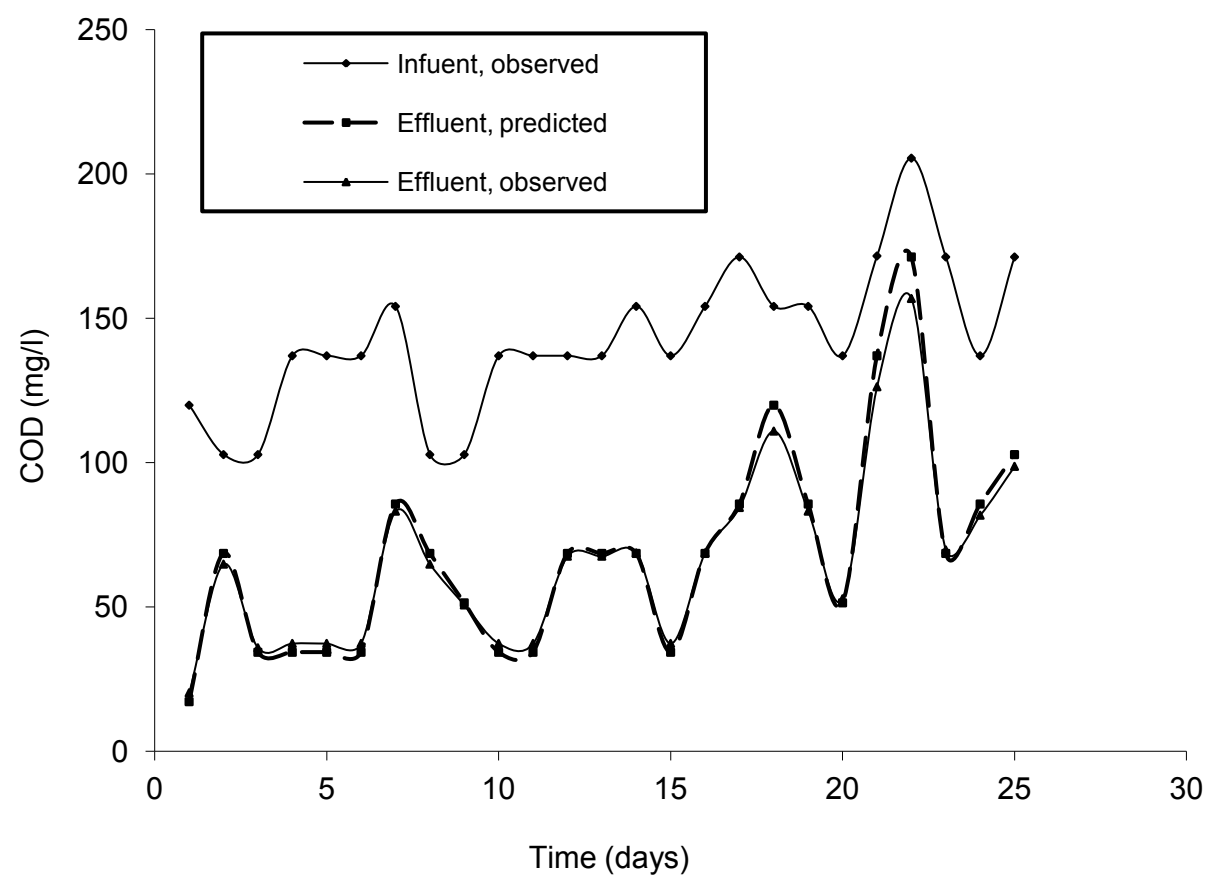

Fig. 4: Variation of influent COD, observed and predicted effluent COD values with time.

\section{REFERENCES}

Brix H. (1995). Functions of macrophytes in constructed wetlands. Wat. Sci. Tech., 29: 71 78.

Cooper P.F., Job G.D., Green M.B. and Shutes R.B.E. (1996). Reed beds and constructed wetlands for wastewater treatment. WRc publications, Medmenham, Marlow, UK.

Duarte C.M. (1992). Nutrient concentration of aquatic plants: patterns across species. Limnol. Oceanogr., 37(4): 882 889.

Farahbakhshazad N., Morrison G.M., Larsson A. and Weisner S.E.B. (1995). Effects of grain size on nutrient removal from wastewater in small-scale planted macrophyte system. In: Natural and constructed wetlands for wastewater treatments and reuse. Ramadori, R., Cingolani, L., Cameroni, L. (ed.), Perugia.

Germain J.E. (1966). Treatment of domestic waste by plastic-medium trickling filter, J. Water Pollut. Control Fed., 38(2).
Gersberg R.M., Elkins S.R., Lyons S.R., and Goldman C.R. (1985). Role of aquatic plants in wastewater treatment by artificial wetlands. Water Res., 20: 363 368.

Greenway M. (1997). Nutrient bioaccumulation in wetland plants receiving municipal effluent in constructed wetlands in tropical Australia. Water Science and Technology, 35(5): 135 142.

Kadlec R.H. and Knight R.L. (1996). Treatment wetland, Lewis publishers, New York.

Kalibbala M., Mayo A.W., Asaeda T., Shilla D. (2008). Modelling faecal streptococci mortality in constructed wetlands implanted with Eichhornia crassipes. Wetland Ecology and Management, 16: 499 510.

Mayo A.W. (2014). Modelling dynamics of organic carbon in water hyacinth Eichhornia Crassipes (Mart.) Solms artificial wetlands. Int. Journ. Wat. Resour. \& Environ. Engng, 6(4): $121 \sim 130$. 
Mayo, A.W. and Bigambo, T. (2005). Nitrogen transformation in horizontal subsurface flow constructed wetland I: Model development. Journal Phy. Chem. Earth, 30: 658 667. http://dx.doi.org/10.1016/j.pce.2005.08.0 05

Mayo A.W. and Hanai E.E. (2017). Modelling phytoremediation of nitrogen polluted water using water hyacinths (Eichhornia crassipes). Journal Phy. Chem. Earth, 100: 170 180, https://doi.org/10.1016/j.pce.2016.10.016

Mayo A.W., Muraza M. and Nobert J. (2018). Modelling nitrogen transformation and removal in Mara river basin wetland upstream of Lake Victoria. Journal Phy. Chem. Earth, https://doi.org/10.1016/j.pce.2018.03.005

Mayo A.W. and Kalibbala M. (2007). Modelling faecal coliform mortality in water hyacinth ponds. Physics and Chemistry of the Earth, 32: 1212 1220.

Metcalf \& Eddy Inc. (1995). Wastewater engineering treatment, disposal and reuse (Third edition). Tata McGraw-Hill, New Delhi.

Mungur A.S., Shutes R.B.E., Revitt D.M. and House M.A. (1997). An assessment of metal removal by a laboratory scale wetland. Water Science and Technology, 35(5): 125 133.

O'Melia C.R. (1995). Particles, pretreatment and performance in water filtration. $J$. Env. Engg., ASCE, 116(6): 874 905.

Perry R.H. and Chilton C.H. (1973). Chemical Engineers Handbook, $5^{\text {th }}$ Edn. McGraw-Hill, New York, USA.

Polprasert C. and Agarwalla B.K. (1994). A Facultative Pond Model Incorporating Biofilm Activity, Water Environment Research, 65(5): 725 732.
Polprasert C. and Khatiwada N.R. (1997). Role of biofilm activity in water hyacinth pond design and operation. In: Proceeding of Asian Water Quality '97 sixth AWQ Asian-Pacific Regional Conference. International Association of Water Quality and Korean Society of Water Quality, Seoul, Korea.

Rogers K.H., Breen P.F. and Chick A.J. (1991). Nitrogen removal in experimental wetland treatment systems: Evidence for the role of aquatic plants. Res. J. Wat. Pollut. Control Fed., 934 941.

Shutes R.B.E., Revitt D.M., Mungur A.S. and Scholes L. (1997). The design of wetland systems for the treatment of urban runoff. Water Science and Technology, 35(5): 19 25.

Standard Methods for the examination of water and wastewater (2012). American Public Health Association, American Water Works Association, Water Pollution Control Federation, 22 ${ }^{\text {nd }}$ Edition, Washington, DC.

Tanner C.C., Clayton J.S. and Upsdell M.P. (1995). Effect of loading rate and planting on treatment of dairy farm wastewaters in constructed wetlands. Wat. Res., 29(1): 17 26.

Thirumurthi D. (1974). Design criteria for waste stabilization ponds. J. Water Pollut. Control Fed., 46: 2095-2107.

Weast R.C. (1981). Handbook of chemistry and physics, 61st ed. CRC press, Boca Raton, Florida.

Zhang D.Q., Jinadasa K.B.S.N., Gersberg R.M., Liu Y., Tan S.K. and Ng W.J. (2015). Application of constructed wetlands for wastewater treatment in tropical and subtropical regions (20002013). J. Environ. Sci., 30: 30 46. http://dx.doi.org/10.1016/j.jes.2014.10.01 